
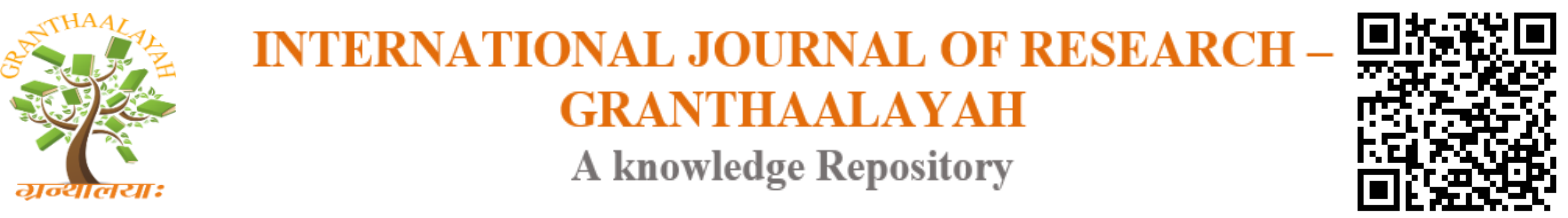

Social

\title{
INFORMATION TECHNOLOGY BASED EMPLOYMENT FACILITATION FOR SKILLED AND UNSKILLED POOR WOMEN IN RURAL AND URBAN AREAS
}

\author{
G.Jayashri ${ }^{1}$, Dr. R. Rajan ${ }^{2}$ \\ ${ }^{1}$ Research Scholar, State Resource Centre, Affiliated to University of Madras, Chennai, India \\ ${ }^{2}$ M.A., M.A, MBA, Ph.D, Associate Professor, Former Director, SRC, Chennai, Currently \\ Associate Professor, Department of Lifelong Learning, School of Education, Alagappa \\ University, Karaikudi - 630003 Tamil Nadu, India
}

\begin{abstract}
Information Technology (IT) is known as a valuable tool for information dissemination. Today, information communication technology can be used as a powerful tool to improve quality and efficiency in creating employment for poor urban and rural women. The increasing development of technology-based tools and their adaptation speed with human requirements has led to a new form of the learning environment and creative, active and inclusive interaction. These days, information is one of the most important power resources in every organization and accordingly, acquiring information, especially central or strategic one can help organizations to build a power base and influence others. The aim of this study was to identify the most important criteria in job empowerment using IT and also the advantages of assessing empowerment.
\end{abstract}

Keywords: Women; Empowerment; Information Technology.

Cite This Article: G.Jayashri, and Dr. R. Rajan. (2017). "INFORMATION TECHNOLOGY BASED EMPLOYMENT FACILITATION FOR SKILLED AND UNSKILLED POOR WOMEN IN RURAL AND URBAN AREAS." International Journal of Research Granthaalayah, 5(8:SE), 96-99. https://doi.org/10.29121/granthaalayah.v5.i8(SE).2017.2282.

\section{Introduction}

Urban and Rural Livelihood Mission are implementing skilling programmes for past 10 years through schemes like Youth Skill Training (YST), Deen dayal Upadhyaya Grameen Kaushalya Yojana (DDUGKY), and National Urban Livelihood Mission (NULM). Nearly 50,000 youth are trained over these years and many are remaining unemployed. Recently Tamil Nadu Skill Development Course (TNSDC) and Pradhan Mantri Kaushal Vikas Yojana (PMKVVY) are also imparting skilling for Lakhs of poor candidates in rural and urban areas. According to Below Poverty Line (BPL) and Participatory Identification of Poor (PIP) survey the youth and employment seekers are identified in families of the Urban and Rural Poor. Job fairs are 
conducted in blocks for placing candidates periodically for providing employment opportunities. Yet it is felt that the employment for poor is not matched successfully.

\section{Demand for More Employment facilitation}

Despite skilling efforts over a decade the unemployment is on the rise. The job seekers aspiration, qualification and the opportunities are not matched for the poor effectively. The skilled and unskilled of poor families have difficulties in finding opportunities for their livelihood. The development in the IT based employment platform like monster.com, naukri.com could not cater to the need of the urban and rural poor to a large extent.

\section{Livelihood Mission as facilitator for employment}

As per PIP and BPL survey the target households are identified by rural and urban livelihood missions. Most of the youth and their skill, aspirations are profiled by Village Poverty Reduction Committee (VPRC), Panchayat level federation (PLF) etc. The skilling programmes like DDU GKY and Employment, Skill Training \& Placement (ESTP) of NULM provide skill to 30,000 youth annually. Hundreds of Job fairs are conducted every year by Tamil Nadu Rura Livelyhoods Mission (TNSRLM). More over TNSDC and PMKVVY seek thousands of candidates from these missions every year. Thus the Rural and Urban livelihood missions stand as the sole facilitator for skilling and employment for rural and urban poor.

\section{Need for IT facilitation in Employment of Poor}

As $30 \%$ of the population is poor in Tamilnadu, data of nearly 10 million families seeking better employment has to be handled. There is a felt need to register their aspiration, skill and present status of employment digitally. There is a need to create a single window interface between the poor job seeks and the job providers. Thus huge volume of data and monitoring has to be handled withexisting machinery of livelihood missions. This is possible by Information technology enabled environment only.

\section{Sources for IT}

State Level Units ofNational Information Center (NIC) and Tamilnadu E - Governance Agency (TNeGA), are resourceful in helping TNCDW for development of Mobile and Web Based Applications. Besides these many IT firms are available in open market for entrusting works for developing web and mobile based applications by tender. We may utilize any of these for development of Mobile and Web Based Applications to support the employment facilitation. The exclusive servers of TNCDW or NIC servers can host and handle the data of the employment facilitation.

\section{Developing App and TOR for Apps}

The IT facilitated employment facilitation with mobile and web applications may have following terms of reference while developing for the benefit of service provider and receiver.

- Geo mapping and tagging

- Tracking of Job providers 
- Registration of Job seekers

- Registration of Job Providers

- Call and Response facilitation

- Tracking of employment
- SMS service and Feedback

- Performance appraisal

- Service Standardization

- Monitoring report generation

Thus a centralized web and mobile based application development is essential for effective functioning of IT facilitation for employment of poor. This may be developed with the help of NIC/ TNeGA /Private IT firms as decided by SMMU of NULM (TN).

\section{Road Map for IT Support for employment}

Following are the steps which may be followed for the development of IT support for employment services to the poor:

- Developing TOR \& RFP for mobile and web services to be offered

- Identification of IT partner through RFP

- Agreement with IT partner(s) shortlisted for Apps

- Development of Mobile and Web based Application

- Creating linkages with Payment services

- Hosting them in Server(s) and Piloting

- Creating Infrastructure in VPRC, PLF, ALF, and CLC for Apps.

- Registering of Urban Poor Job seekers en masse

- Popularization of services of and Job providers mobilization

- Delivery of Services thro app facilitation

- Managing the web and Mobile assisted employment services for Poor

\section{Consequences}

The most important consequences of IT application in women empowerment include:

- Increase women' job opportunities

- Increase decision-making responsibilities among women

- Increase women' independence and freedom

- Increase women' knowledge and awareness

- Minimize human errors in processing information and higher service providing which lead to high satisfaction and emphasized on the role of IT in women' performance improvement

- IT leads to a better performance accompanied by higher efficiency in service providing all of which will cause more satisfaction from fast and high-quality services.

\section{Conclusion}

Information plays a vital role in programming, evaluation and administration of management systems. Therefore, the IT decreases human resources role and results in a systematic relation between human and machine. As rural and urban women are also an important resource and it's necessary and unavoidable to pay enough attention to them in order to achieve Government objectives one of the important ways of women empowerment is education and access to 
information through topical technologies. IT is one of tools and mechanisms that collect categorize and process information and provide the results.

\section{References}

[1] Alvani M. 2nd ed. Tehran: Ney Publishing; 2009. General Management; p. 32.

[2] Arab-Chadegani R. Increasing quality of hospital procedures by using hospital information system (HIS) [Last accessed on 2013 Jun 10]; Adv Enviroment Biology. 2013 7:1466472. Available from: http://www.aensiweb.com/aeb/2013/1466-1472.pdf .

[3] Beheshtian M, Abolhassani H. Tehran: Pardis Publications; 2010. Management Information Systems; p. 20.

[4] Golden, S. A. R. (2017). Recent Research in Social Sciences \& Humanities. EduPedia Publications (P) Ltd.

[5] Golden, S. A. R., \& Regi, S. B. (2013). Mobile commerce in modern business era. International Journal of Current Research and Academic Review, 1(4), 96-102.

[6] Golden, S. A. R., \& Regi, S. B. (2015). Satisfaction of Customers towards User Friendly Technological Services offered by Public and Private Sector banks at Palayamkottai, Tirunelveli District. International Journal of Research, 2(3), 775-787.

[7] Golden, S. A. R., Regi, S. B., \& Franco, C. E. (2014). A study on Impact of Information Technology (IT) in Modern Banking Sector. Golden Research Thoughts, 3(11), 1.

[8] http://www.tamilnadumahalir.org/document.html

[9] Lavdn K. Translated by Hamid M. Tehran: Publications Librarian; 2001. Information Technology. "Mutram” Tamil Magazine from Jan'15 - Sep'17.

[10] Morales S. Impact of information technology on users. Translation by Rezvandokht Z. Faslname Ketab. 1990:256-71.

[11] Rafiee M, Kusha M. Paper Presented at the Second International Conference on Project Management.Tehran, Iran: 2005. The role of risk management in IT projects.

[12] Regi, S. B., \& Golden, S. A. R. (2014). A Study On Attitude Of Employee Towards Working Environment With Special Reference To RR Pvt Ltd. Review Of Research, 2 (2), 1, 5.

[13] Regi, S. B., \& Golden, S. A. R. (2014). Attitude of Rural People Towards Technology Inclusion In Banking Services At Tirunelveli District. IGJAE-Indo Global Journal Of Applied Management Science, 2 (2).

[14] Regi, S. B., Golden, S. A. R., \& Franco, C. E. (2014). A DESCRIPTIVE STUDY ON THE PROSPECTS OF E-COMMERCE IN INDIA. Golden Research Thoughts, 3 (9), 1, 7.

[15] Whetten DA, Cameron KS. Tehran: Institute of Management Education and Research; 2002. Developing Management Skills (4th Edition) Translated by Badredin Urei Yazdi; p. 51. 